\title{
The Spectre of Fear in the Dystopia of The Hunger Games: An Analysis of the Linguistic Indicators of Point of View
}

\section{Rania Abdel Meguid}

Assistant Professor, Faculty of Arts, Alexandria University, Egypt.

\begin{abstract}
Recent years have witnessed a spike in the sales of dystopian fiction, especially in the category of post-apocalyptic literature. Moreover, dystopian fiction is no longer directed to adults only, for many post-apocalyptic works fall now under the category of young adult (YA) literature. The massive production and consumption of such works, which present a pessimistic and catastrophic vision of the world, reflect the fear that has invaded the world since the 1960s due to the effects of the Cold War. One major post-apocalyptic work that was produced in the last few years is Suzanne Collins' The Hunger Games trilogy (published in 2008, 2009 and 2010) which presents a sinister view of the future, hence warning against the consequences that are to be expected should authoritarianism remain unchecked. The linguistic choices made by an author contribute to the construction of the message he/she is trying to convey. Hence, this paper aims to analyze the linguistic indicators of point of view, proposed by Short (2013) and Black (2006), in Collins' first book of the trilogy in an attempt to investigate how such indicators contribute to creating an atmosphere of gloominess and uneasiness. Such atmosphere serves as a warning against a catastrophic future to be expected should dictatorships and totalitarian regimes be allowed to last.
\end{abstract}

Keywords: Dystopian Fiction, Post-Apocalyptic Literature, The Hunger Games, Authoritarianism, Totalitarian Regimes, Point of View 


\section{Introduction}

Recent years have witnessed a massive increase of the sales of dystopian works of art depicting societies living under totalitarian regimes. For example, in 2017, George Orwell's 1984 topped the Amazon best-seller list in the United States to the extent that publishers had to order thousands of new copies as the book flew out of bookstores (de Freytas-Tamura, 2017, para. 1-2). It was argued that the election of Donald Trump as president was behind such phenomenon ("Dystopian books see impressive sales boost," 2017, para. 2).

Dystopian works of art, especially post-apocalyptic works (i.e. works depicting life after the world has been struck by a disaster), are no longer directed to adults alone; many postapocalyptic works of art are now directed to young adults. One major work of art that has attracted wide readership is Suzanne Collins' The Hunger Games trilogy which was published between 2008 and 2010. The trilogy presents a dark and sinister view of the future which sounds like a warning of how the future of humanity could be like should totalitarian regimes continue to rule the world. Using the linguistic indicators of point of view proposed by Short (2013) and Black (2006) as a theoretical framework, the paper aims to investigate how the linguistic choices made by the author in the first book of the trilogy contribute to constructing a dystopian world where human souls are crushed under the rule of an authoritarian government. Such linguistic choices serve to trigger the readers' imagination so that they would be able to have a vision of their own future if they allow the current situation to remain unchanged.

\section{Review of the Literature}

\subsection{Dystopian Fiction}

In order to understand what is meant by dystopian fiction, the term "dystopia" needs first to be understood. The term "dystopia" is the opposite of the term "utopia" which, in fact, appeared first. According to Kirtley (2011, p. 120), the term "utopia" was first used in 1516 by St. Thomas More in order to refer to "an ideal place, an imaginary island of harmonious existence". The term consists of the two parts: "topia", which is the Greek word for "place", and "eu", which means "good".

The idea of utopia was greatly influential in the writing of fiction. With the publication of Thomas More's Utopia, the genre of utopia became an umbrella genre with several categories which started forming under it, the most radical among which is dystopian fiction (Gleyzer, 2018, pp. 13-14).

The word dystopia was first introduced by John Stuart Mill in his speech in which he denounced the British government's Irish land policy (Kirtley, 2011, p. 120). The word "dystopia", like its opposite "utopia", consists of two parts: "dys-" and "topia" which mean "bad" and "place" respectively. A dystopian society is created by a totalitarian or authoritarian government, which leads to the loss of individual freedom due to untenable living conditions, living under constant surveillance and the government controlling people's sexual and reproductive freedom (Mathichiparampil, 2016, p. 181). Against this backdrop, many authors tend to equate totalitarianism with dystopia (Claeys, 2017, p. 5).

Dystopian fiction is a very popular subgenre of science fiction. According to Curwood (2013, p. 418), science fiction has been extremely popular for a number of reasons. One reason for the popularity of science fiction is that reading works which belong to this genre requires a suspension of disbelief; readers need to imagine new worlds and ways of being in order to be able to understand science fiction. Another reason is that although science fiction narratives 
take place in imaginary worlds, readers can still relate to the moral dilemmas and personal struggles in such works of fiction. Accordingly, science fiction is "capable of achieving profound and probing insights into the principal dilemmas of political life" as it questions "the foundation of new political orders, the endeavour to realize utopia, the exigencies underpinning tyranny, the relationship of a saintly politics to the practice of realpolitik, and the potential and limitations of radical politics in the present age" (Paik, 2010, p. 1). Science fiction presents imaginary worlds that, though drastically different from the real world, exhibit consistency and coherence just like the real world. Accordingly, science fiction presents "visions in which familiar realities are destabilized and transformed" with the aim of helping the readers to conceive of the contemporary situation by comparing it to the imaginary world they are reading about, which helps them criticize their own reality. Comparing a work of science fiction to the readers' own reality can help them criticize real political institutions as well as the injustices and oppressions plaguing their own society (ibid, pp. 2-3).

According to Gleyzer (2018, p. 14), dystopian fiction appeared as a definitive subgenre of science fiction only in the late $19^{\text {th }}$ century when the works of Wells, Zamaytin, Huxley and Orwell started defining what a dystopia is. The works of those writers created an atmosphere of "literary pessimism" through creating dystopian worlds based on industrialization, statecontrolled media, censorship and manufacturing a prenatally conditioned population (Hammond, 2017, p. 102). As Miller (2010, para. 3) argues, dystopian stories, like 1984 and Brave New World, warn us about the dangers that could threaten society should totalitarianism and authoritarianism remain unchecked, and this is through detailing "the consequences of political authoritarianism and feckless hedonism" as if the message such works are trying to convey to the readers is "[t]his is what will happen if we don't turn back now". Kay Sambell (as cited in Mathichiparampil, 2016, p. 180) offers two key elements of a dystopian work: first, it warns readers against the consequences of current human behaviour, and second, it presents a hopeful solution. As Davis (2014, p. 50) explains, dystopian novels "serve as cultural critiques and models as to what might happen if we pursue some of our present courses", and as Sambell (as cited in Miller, 2010, para. 3) argues, the warning message conveyed by a dystopian work becomes more shocking and fearful the more utterly the protagonist is crushed. Keith M. Booker (as cited in Gleyzer, 2018, p. 90) distinguishes three factors which are found in dystopian fiction; these are "[p]roducing obedience, manipulating specific behaviors, and engineering individuals". Hence, what dystopian writers, in fact, do is "adapt[ing] the mistakes of relevant historical events to their own storylines".

Finnsson (2016, p. 5) argues that major world changing events usually lead to the creation of dystopias, resulting in the production of dystopian fiction, and chief among these changes are plague, a third world war, asteroids or even zombies. Such events lead to the destruction of civilizations and the creation of dystopias marked by fear and control in an attempt on the part of governments to maintain the little remaining social structure through the use of power and violence (ibid, pp. 5-6), and the Cold War is a case in point. There has been a massive increase in the production of dystopian fiction since the 1960s, and this was mainly due to the effects of the Cold War which resulted in spreading uneasiness over economic crises and anxiety about the future. Accordingly, as Ames (2011, p. 4) argues, analyzing the sociopolitical commentary presented by dystopian works of art "provides insights into the concerns [a] generation may have for the future". This is through "tak[ing] our history, the experience of world leaders, and paint[ing] their colors truthfully but in the most horrifying undertones" (Gleyzer, 2018, p. 110). 


\subsection{Post-Apocalyptic Fiction}

According to Heise (as cited in Hicks, 2016, p. 8), all post-apocalyptic narratives belong to the category of dystopian fiction. As Gleyzer (2018, p. 15) explains, dystopian fiction has subgenres, chief among which are apocalyptic narratives, which take place in a world in the midst of crumbling, and post-apocalyptic narratives, which take place in a world that has already been struck by a disaster. Although it is not easy, Hicks (2016, p. 7) argues, to "tease apart the impulses of the apocalyptic and the dystopian", it is possible to distinguish between dystopian fiction and post-apocalyptic fiction, for the former concentrates on "how humanity survives after world-changing events", whereas the latter focuses more on "how people survive and evolve in their new circumstances" (Gleyzer, 2018, pp. 15-16). In other words, a postapocalyptic world is one where there is no place except for "armed looters, rogue military, biker gangs, petty tyrants, cults, crazies, infected, and other desperate scum who want to deprive you of life, liberty, and the pursuit of happiness" (ibid, p. 27). Accordingly, apocalyptic and post-apocalyptic narratives serve psychological and political purposes, for they serve as a means of denouncing social and economic injustice (Hicks, 2016, p. 14).

Post-apocalyptic fiction has become increasingly popular. Numerous post-apocalyptic narratives have always topped best-selling lists and have been turned into successful blockbusters and television series (e.g. Collins' The Hunger Games). Such success seems to be due to the fact that those works echo the "severe economic crises, environmental concerns, fear of technological failures, and even political scandals" that modern society has been suffering from (Gleyzer, 2018, p. 16). Like dystopian fiction, post-apocalyptic fiction seems to convey a powerful warning message about the future of humanity should humans pursue the same courses of behaviour.

\subsection{Young Adult (YA) Fiction}

According to Burke (2014, p. 1), the early $21^{\text {st }}$ century will be one day recognized as a golden age for young adult literature due to the massive production of young adult works of art and such novels becoming "multi-million dollar entertainment empires". One of the main genres dominating YA fiction is the dystopian/post-apocalyptic genre. As Hicks (2016, p. 138) puts it, "[t]he proliferation of post-apocalyptic plots in the young adult genre is hard to miss".

Many works of dystopian fiction have started being directed to young adults since the 1970s (Finnsson, 2016, p. 6). Kirtley (2011, p. 120) argues that this is probably due to the fact that youngsters of the modern world have never experienced a world free from war. As Hicks (2016, p. 25) puts it, the massive production of post-apocalyptic YA fiction signifies the vitality of this genre for young adult readers and suggests how writers "sense the relevance of this genre, both as writers and as citizens of the contemporary world". Introducing post-apocalyptic works of art to young adults gives them the opportunity to "evaluate socioeconomic inequity in an imaginary world and consider potential solutions" (Kirtley, 2011, p. 120). In other words, this genre could be considered a gateway for teenagers to the adult world, for it "acts as an initiator into the dark underbelly of the adult world" (Mathichiparampil, 2016, p. 180). Therefore, YA works of art are usually didactic and shocking in an attempt to teach young adults "to question social and cultural impositions and discern the politics of corruption" (Davis, 2014, p. 50). This is because such works draw parallels between imaginary dystopian worlds and the real world, encouraging teenagers to think about the politics of their world and the conditions of the society they live in (Davis, 2014, p. 51). Among the most important postapocalyptic novels which are directed to young adults is Suzanne Collins' The Hunger Games which is analyzed in this paper. It is a novel which presents a futuristic view which is extremely 
pessimistic and which sounds like a warning to the readers against the grave consequences of authoritarianism.

\section{Methodology}

This paper presents a stylistic analysis of Suzanne Collin's The Hunger Games, the first book of The Hunger Games trilogy, with the aim of investigating how the linguistic choices made by the author contribute to creating an atmosphere of gloominess and uneasiness in the scary dystopian world of the novel. The linguistic model used in the analysis comprises the linguistic indicators of point of view proposed by Short (2013) and Black (2006) which are used mainly to analyze fiction (i.e. novels and short stories).

\subsection{The Discourse Structure of a Novel}

According to Leech and Short (1981, p. 257), a spoken discourse occurs in a discourse situation that consists of the following elements:

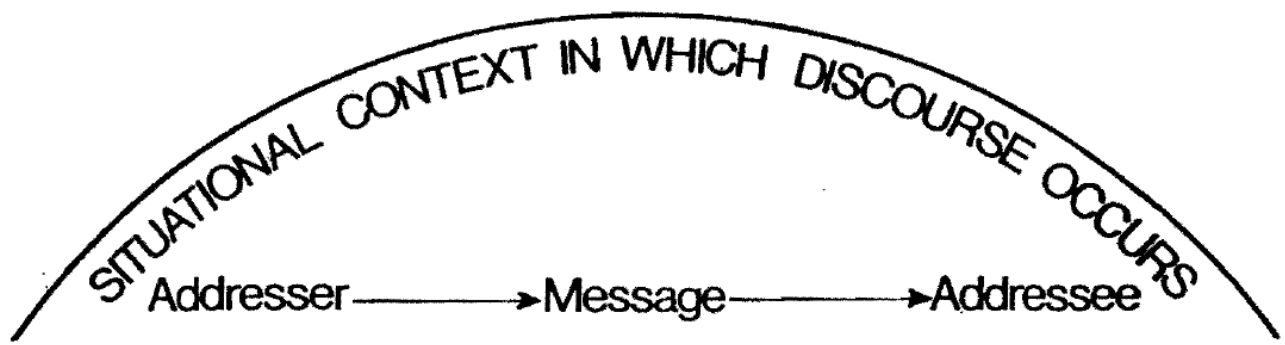

Short (2013, pp. 256-257), however, argues that in order to account for the structure of a novel or a short story, at least three levels of discourse are needed. To start with, a novel or a short story itself is a message produced by an author and intended to be received by a reader, which constitutes the first level. The second level comprises the narrator of the story (which is not to be confused with the author) and the narratee (which is not to be confused with the reader). Level 3 comprises the interaction between the characters within the story. The discourse structure of a novel or a short story, according to Short, can be represented as follows:
Addresser 1
Message
Addressee 1
(Novelist)
(Reader)
Addresser $2 \quad$ Message
Addressee 2
(Narrator)
(Narratee)

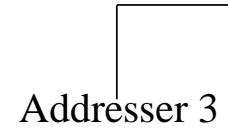
Message
Addressee 3
(Character A)
(Character B)

This structure illustrates that there are more viewpoints to be taken into account in the analysis of fiction than in other genres like poetry and drama, which is why "the novel is the most complex genre in terms of discourse structure" (Short, 2013, p. 256). Moreover, this structure is collapsible. The narrator-narratee level might collapse into the character-character level when the narrative is in the first-person. In addition, sometimes (e.g. in autobiographies) the 
borders between the three levels are blurred when the narrator is the author and at the same time a character in the story (Short, 2013, p. 260).

Discussing viewpoint is discussing the distinction between "what" is described and "how" or "from whose perspective" it is being described. When reading fiction, readers understand the events in the light of the how they are described, and hence, such events cannot be verified independently from the way they are described (Short, 2013, p. 256). Accordingly, discoursal view point can be defined as "the relationship, expressed through discourse structure, between the implied author or some other addresser and the fiction" (Leech and Short, 1981, p. 272).

\subsection{Indicators of Point of View in fiction}

Viewpoint in fiction is controlled by a number of choices made by the author, some of which are the result of manipulating the discourse structure of the novel/short story, while the others are linguistic choices made by the author.

\subsubsection{Type of Narrator}

\subsubsection{First-Person Narrator (I-Narrator)}

Sometimes the narrator is one of the characters in the story, in which case the narrator is referred to as a first-person narrator or an I-narrator (since the pronoun "I" is used by the narrator to relate the narrative). It is generally thought that the views presented by a first-person narrator are limited as he/she does not know all the facts (Short, 2013, p. 257). Accordingly, "the narrator should not make assertions about the motives, thoughts or intentions of the other characters in the fiction" (Black, 2006, p. 56). In addition, a first-person narrator is thought to be unreliable, for he/she might withhold facts (like committing a murder) or might be mentally disadvantaged (Short, 2013, pp. 257-258).

\subsubsection{Third-Person Narrator}

Third-person narratives are narratives that make use of third-person pronouns (e.g. "he", "she" and "it"), and they are much more omniscient than first-person narratives (Short, 2013, pp. 258-259). This is because a third-person narrator has "the ability [...] to enter into the minds of characters in the fiction" (Black, 2006, p. 61).

\subsubsection{Linguistic Indicators of Point of View 3.2.2.1. Schema-Oriented Language}

Different participants in the same situation have different schemas (i.e. knowledge about the world) reflected in their use of language and reflecting of their own viewpoints. Choosing "what" to describe and the different vocabulary items used by those participants signify their different viewpoints (Short, 2013, pp. 264-265).

\subsubsection{Value-Laden Expressions}

In addition to choosing "what" to describe, "how" it is described reflects a character's point of view. Expressions that are evaluative in nature (e.g. adjectives and adverbs) are indicative of a character's viewpoint (Short, 2013, p. 265).

\subsubsection{Given vs. New Information}

Linguists distinguish between what they call "given" vs. "new" information. New information is information that is not already known to the addressee and is usually referred to using an indefinite article, whereas given information is information already known to the addressee and is usually referred to using a definite article (Short, 2013, p. 266). In addition, 
definite articles are used to refer to unique items (e.g. "the sun") (Black, 2006, p. 5). Presenting information as given or new is indicative of a character's viewpoint. Moreover, in so doing, the addressee's viewpoint is taken into account. For example, using an expression like "a sun" instead of "the sun", when the sun is expected to be known to the addressee, implies that the entity referred to in the text is a sun that is different from the one that is already known.

\subsubsection{Indicators of a Particular Character's Thoughts or Perceptions}

A character's viewpoint can be indicated by the use of verbs of perception and cognition as well as adverbs related to factivity. For example, the verb "know" indicates factivity, the verb "pretend" is counter-factual and the verb "believe" is non-factive (Short, 2013, pp. 268269).

\subsubsection{Deixis}

The term "deixis" is used in linguistics to indicate "pointing words". Deictic expressions are speaker-related, so they "can be used to indicate particular, and changing, viewpoints" (Short, 2013, p. 270). Through the combination of proximal (close) and distal (distant) deixis, the author is able to establish the spatio-temporal perspective of a narrative (Black, 2006, p. 5).

\subsubsection{Social Deixis}

Social relations are deictic in the sense that a speaker/character might feel close or remote to other characters in social terms. Hence, using the first name of another character indicates closeness, whereas using the last name + a title indicates remoteness (Short, 2013, p. 272). Accordingly, social deixis is used in fiction to encapsulate the fluctuating relationships between characters, which is indicative of viewpoint in fiction (ibid, p. 273).

\subsubsection{The Sequencing and Organization of Actions and Events}

The organization of clauses in a narrative can be used for viewpoint manipulation in a way which could be termed "psychological sequencing". In other words, information could be temporarily withheld instead of being given straightaway to indicate the perceptions of a character (Short, 2013, p. 275).

\subsubsection{Ideological Viewpoint}

The use of a number of the above-mentioned indicators can be reflecting of the ideological viewpoint of a character, indicating his/her mind-set or outlook on the world (Short, 2013, p. 277).

\subsubsection{Tense}

Tense is thought to function deictically in a narrative since it locates the events of a narrative in time. The normal tense to be used in fiction is the simple past since a story is "told by a narrator who relates events as though they are past" (Black, 2006, p. 6). However, sometimes the present tense is used to narrate past events "to suggest simultaneity of narration and event" and is referred to in this case as "historical present" (Black, 2006, p. 7).

Having presented the model of analysis, this paper aims to analyze the narrative structure of Suzanne's Collins The Hunger Games (the first book in the trilogy) as well as the linguistic indicators of point of view in the novel to investigate how the narrator, who is also a

character in the novel, expresses her feelings towards living in Panem, which is a dictatorship and, hence, a dystopia. The analysis also aims to examine how the linguistic choices made by 
the author (being reflected through the narrator's perception) are revealing of the horrifying conditions the people of Panem are forced to live under.

\section{Data}

The data analyzed in this paper is Suzanne Collins' The Hunger Games which is the first book in her trilogy of the same title. The story traces the life of 12-year-old Katniss Everdeen, a citizen of District 12 of Panem. At some point in history, the governments of North America collapsed, and in their stead emerged the country of Panem with the Capitol as its capital. A war between the Capitol and the 13 districts of Panem resulted in the demolishing of District 13 and the Capitol avenging itself on the remaining 12 districts for the rebellion. Accordingly, every year there is a "reaping" ceremony in which a boy and a girl are chosen from each district to take part in the Hunger Games in which the 24 tributes, whose names happen to be written on scraps of paper chosen blindly on the reaping day, are thrown into an arena where they have to fight each other to death until there is only one winner (i.e. one survivor). The Games serve as a reminder of the defeat of the districts before the Capitol as well as a threat that forbids them from thinking of another rebellion.

On the reaping day of the $74^{\text {th }}$ Hunger Games, people gather as usual in one of the city squares. To Katniss' horror, the female tribute chosen for the Games this year is Prim Everdeen, Katniss' little sister. Katniss volunteers in her stead, and the government accepts her offer. Accordingly, she joins the Games along with Peeta Mellark, the other tribute who is the son of a baker and who used to secretly give bread to Katniss and her family. Katniss' family, like almost all the other families in the district, lives in abject poverty, and sometimes they can barely find food. But for Katniss' excellence in hunting, which she learned from her father before he was killed in a mine explosion, they would not have survived. Accordingly, Katniss would go into the woods with her friend Gale to hunt, which is an act punished by death in Panem. The only thing that keeps her from punishment is that the officials are her best customers.

After being chosen to take part in the Hunger Games, Katniss and Peeta, along with the tributes from the other districts, are taken by train to the training center located at the Capitol where they get trained form the Games. During the period between leaving the districts and the beginning of the games, the tributes experience luxury they have not dared to dream of before. They are offered the best food, clothes and living conditions, which feels more humiliating when they are on the verge of death. Once the Games start, they face the most fearful, the most inhumane and the most humiliating conditions one could think of, especially knowing that these Games are being aired live and the audience are being entertained. Eventually, Katniss and Peeta rise as winners after they live a most deadly experience during the Games.

It has been argued that Collin's The Hunger Games, along with many other recent dystopian, post-apocalyptic works of art, serve as a warning of what our future in reality would be like should authoritarianism and totalitarianism remain unopposed. According to Kirtley (2011, p. 122), Collins states that she has created such a scary dystopian world in an attempt to characterize current and past war events, and as an example of these events, she draws attention to the use of hunger to control populations and the elimination of the rights of individuals. As Burke $(2014$, p. 1) puts it, Collins creates a dystopian world where the population does not have access to or control over the means of food production. Burke thinks that "The Hunger Games investigates the potential end results of our current politics, the reality of the dystopia we live in now." This is because it presents a speculation of the future of the United States in which people will suffer immensely as a result of being manipulated with hunger and starvation (p.22). This fear has been intensified, especially after the financial insecurities resulting from 
the stock market crash in 2008 (Gleyzer, 2018, p. 1). This could be seen as paralleled in the novel by Katniss wishing she and her family, who lead a miserable life in which they almost starve to death, could only satisfy their basic needs through having an ample supply of food and drink. According to Leggatt (2012, p. 11), The Hunger Games presents a dystopian world whose citizens are clearly divided along class lines, for it expresses "the rich/poor dichotomy upon which the futuristic dystopia is - somehow unavoidably - founded" (p. 12). Accordingly, The Hunger Games reflects "different dimensions of power play and the ultimate success of the dominant power structure," and hence, it represents "a hyperreality which may be regarded as a hyperbolical representation of the present-day world" (Mathichiparampil, 2016, p. 180). In short, The Hunger Games could be seen as presenting a catastrophic vision of the future in order to help us "remind ourselves of the bleakness of the future, like trying to pinch oneself in order to wake up as if from a nightmare unfolding" (Leggatt, 2012, p. 13).

\section{Data Analysis}

This section presents an analysis of a number of key passages in Suzanne Collins' The Hunger Games using the linguistic indicators of point of view proposed by Short (2013) and Black (2006). The aim of this analysis is to investigate how the linguistic choices made by the novelist contribute to creating a dark and sinister atmosphere and presenting a scary image of the dystopian world of Panem in what seems like a warning against what our future would be like in reality should we allow totalitarianism and authoritarianism to continue to rule.

To start with, in terms of discourse structure (see section 3.1), the narrator of the novel is Katniss Everdeen who is also the main character. Hence, the story has a first-person narrator after the narrator and the character levels have collapsed into one. Even though Short (2013, pp. 257-258) and Black (2006, p. 56) criticize a first-person narrator as being unreliable, for he/she cannot "make such categorical assertions about another's state of mind" (Black, 2006, p. 56), and untrustworthy, for he/she may be mentally disadvantaged or willing to mislead the reader, this does not seem to be the case in Collins' novel. Instead, writing the novel as a firstperson narrative seems to draw the readers closer to the narrator and make them more able to understand her feelings and delve deep into her thoughts. The readers' ability to connect personally with Katniss and understand her feelings and thoughts seems to be of paramount importance as she is the best person to express her own feelings. Hence, the readers are able to sympathize with her throughout the story: when her family is almost starving to death, when she goes out to search the garbage for crusts of bread for her family, when she remembers her father who died in a mine accident, when she is horrified after her little sister has been chosen as a tribute for the Hunger Games, which urges her to volunteer in her stead, and when she suffers immensely throughout the cut-throat Games from all sorts of torture including dehydration, starvation, bleeding almost to death and lack of medicine when she is in dire need for it, let alone being psychologically depleted at the death of the other tributes and being unable to even sympathize with them when she knows very well that their life means her own death. In fact, using the pronoun "I" throughout the novel to narrate the events seems to be a suitable choice. In this book, the readers get to see Panem and the Games through the eyes of Katniss who is herself one victim of Panem. Living through her feelings and thoughts gives the readers the opportunity to experience what she has been living through, which adds to the horrific picture the novel is trying to create of the dystopian world of Panem. Living through the feelings and thoughts of the person who narrates the story, indeed, contributes to creating a scary image of Panem, which serves as a warning against allowing the establishment of a dystopia in our real world.

At the very beginning of the novel, the readers are introduced to Katniss' family and house. Katniss gives a detailed description of her home in the following lines: 
"When I wake up, the other side of the bed is cold. My fingers stretch out, seeking Prim's warmth but finding only the rough canvas cover of the mattress. She must have had bad dreams and climbed in with our mother. Of course, she did. This is the day of the reaping.

I prop myself up on one elbow. There's enough light in the bedroom to see them. My little sister, Prim, curled up on her side, cocooned in my mother's body, their cheeks pressed together. In sleep, my mother looks younger, still worn but not so beaten-down. Prim's face is as fresh as a raindrop, as lovely as the primrose for which she was named. My mother was very beautiful once, too. Or so they tell me.

Sitting at Prim's knees, guarding her, is the world's ugliest cat. Mashed-in nose, half of one ear missing, eyes the color of rotting squash. Prim named him Buttercup, insisting that his muddy yellow coat matched the bright flower. He hates me. Or at least distrusts me. Even though it was years ago, I think he still remembers how I tried to drown him in a bucket when Prim brought him home. Scrawny kitten, belly swollen with worms, crawling with fleas. The last thing I needed was another mouth to feed." (Collins, 2008, pp. 3-4)

The linguistic indicators of point of view used in these lines, which appear at the very beginning of the novel, are significant. The first thing that could be noticed about the extract (which will continue till the end of the book) is that the book is entirely narrated in the present tense as if the events narrated are taking place at the time of narration even though, of course, the events narrated are all past events. This use of the present tense to narrate past events (known as "historical present") suggests "simultaneity of narration and event" (Black, 2006, p. 7), which makes the readers almost able to visualize them like they are seeing them happening now. This could be seen as contributing to the involvement of the readers in the events, which might intensify their feelings as they go on reading.

In addition to the tense, the value-laden expressions used by the I-narrator are reflecting of the hard life she and her family are leading in District 12 in Panem. This appears in the very first sentence in the novel with the use of the adjectives "cold" and "rough". The words describe how the side of the bed feels when Katniss (the narrator) does not find her sister, but they also seem to reflect the kind of life the family leads, a "cold" and "rough" life created by poverty and need. The adjectives "curled up" and "cocooned" used to describe Prim reflect her fear and need for security, feelings which have always dominated the family in the authoritarian state, especially with the death of the father in a terrible mine accident, not to mention that today is the day of the reaping when the tributes will be chosen to participate in the Hunger Games. Prim's fear at the beginning of the book seems to foreshadow the catastrophe that is soon to befall the family (the choice of Prim as a tribute and then Katniss volunteering in her stead). Katniss also sees Prim's face as "fresh", which reflects Katniss' compassion for her and conveys a sense of innocence, given the fact that Prim is pretty young. It also foreshadows Katniss volunteering instead of her for the Games, for Katniss feels a sense of responsibility for her. There is also a description of Katniss' mother as looking "worn" in sleep though she looks "younger" too. Looking "worn", as the readers get to know later from the narrative, is due to the hardships the mother had to go through to raise her daughters. She is a woman who has always suffered from poverty and who was devastated by the loss of her husband, so now she looks "worn", even though she used to look beautiful at some point, due to the hard life she has always led.

In addition to describing the house, the mother and the sister, Katniss provides a detailed description of her sister's cat, and this description contributes significantly to the 
sinister atmosphere Katniss creates throughout her narrative. To start with, it is described as "the world's ugliest cat" before this ugliness is described in detail: its nose is "mashed-in", half of its ear is "missing" and its eyes have the colour of "rotting squash". Moreover, when it was first brought to the house, it was "scrawny", with a belly "swollen with worms" and "crawling with flees". All these adjectives and adjectival phrases intensify Katniss' view of the cat as extremely ugly, and hence reflect her hatred for it. However, a couple of lines later, the readers get to know the real reason for such hatred; Katniss does not want more mouths to feed as her family is already suffering from abject poverty and she can hardly afford for the poor family. Hence, the value-laden expressions that Katniss uses to describe her family and her house contribute to indicating how miserable the family's life is as a poor family living in the poorest district and belonging to the lowest class of society in Panem.

Presenting information as new or old plays a role in conveying point of view in fiction. In the very first paragraph of the novel, Katniss talks about "the reaping". Even though it is still the beginning of the novel, presenting "the reaping" as "given information" using the definite article positions the readers as already "in the know", which helps them "to feel intimately involved with what is going on in the beginning of [the] story" (Short, 2013, p. 267). The readers in this case are forced to take a position as if they already know what "the reaping" refers to, which helps them to feel much closer to the events of the story as well as to Katniss' thoughts and feelings. She feels how "cold" and "rough" the bed is just a couple of lines before she mentions that this is the day of "the reaping", which creates an atmosphere of uneasiness and urges the readers to think of this reaping as an unpleasant incident. This contributes to arousing the readers' fear of what takes place in this dreadful society.

The narrator also uses a number of indicators of her thoughts and perception, which establishes point of view in the narrative. In the sentence "[s]he must have had bad dreams", the modal verb "must" indicates factivity and shows that Katniss knows that this probably is not happening for the first time. Misery has always been a companion of the family, and this seems to have resulted in nightmares visiting Prim frequently. The verb "looks" in the sentence "my mother looks younger" reflects how Katniss sees her mother as seeking solace in sleep since all the waking hours are full of suffering. She seems to find solace in sleep, and hence, she does not look as weary as she looks during the waking hours during which she has to suffer.

The family shortly afterwards has to go to attend the reaping ceremony. Katniss already feels tense, but she is blown by surprise when her little sister Prim is chosen as a tribute. In the following lines, she describes how she feels:

"One time, when I was in a blind in a tree, waiting motionless for game to wander by, I dozed off and fell ten feet to the ground, landing on my back. It was as if the impact had knocked every wisp of air from my lungs, and I lay there struggling to inhale, to exhale, to do anything.

That's how I feel now, trying to remember how to breathe, unable to speak, totally stunned as the name bounces around the inside of my skull. Someone is gripping my arm, a boy from the Seam, and I think maybe I started to fall and he caught me.

There must have been some mistake. This can't be happening. Prim was one slip of paper in thousands! Her chances of being chosen so remote that I'd not even bothered to worry about her. Hadn't I done everything? Taken the tesserae, refused to let her do the same? One slip. One slip in thousands. The odds had been entirely in her favor. But it hadn't mattered. 
Somewhere far away, I can hear the crowd murmuring unhappily as they always do when a twelve-year-old gets chosen because no one thinks this is fair. And then I see her, the blood drained from her face, hands clenched in fists at her sides, walking with stiff, small steps up toward the stage, passing me, and I see the back of her blouse has become untucked and hangs out over her skirt. It's this detail, the untucked blouse forming a ducktail, that brings me back to myself.

"Prim!" The strangled cry comes out of my throat, and my muscles begin to move again. "Prim!" I don't need to shove through the crowd. The other kids make way immediately allowing me a straight path to the stage. I reach her just as she is about to mount the steps. With one sweep of my arm, I push her behind me.

“I volunteer!” I gasp. "I volunteer as tribute!'”' (Collins, 2008, pp. 25-26)

In this scene, Katniss describes her shock when Prim is chosen as a tribute for the Hunger Games before she, Katniss herself, volunteers in her sister's stead. She begins with narrating an accident which happened to her before. In the first paragraph, the distal deictic "one day" is used, and the narrative is told in the past tense since the accident took place at a time prior to the time of narration before coming back to the arena in which the reaping is taking place. The shift between the past tense and the present tense helps Katniss to draw a comparison between a past death experience and the horror she is feeling now. The use of the proximal deictic "now" in the sentence "[t]hat's how I feel now" (paragraph 2) helps indicate the perspective of the narrator and gives a sense of immediacy, which draws the reader closer to the text and helps them visualize the event as if it were happening before their very eyes. The shift between the past and present tenses (and hence distal and proximal deixis) also helps the readers imagine the horrors Katniss has been experiencing throughout her life. Fear in Katniss' life is not a temporary guest, but a permanent resident that has accompanied her since the past until the time of narration.

The value-laden expressions Katniss uses are also indicative of her shock and horror. The adjective "unable" in the adjectival phrase "unable to speak", in addition to the adjective "stunned" (paragraph 2), express Katniss' shock and horror when she hears her sister's name after the latter has been selected as a tribute. The description Katniss gives of Prim in the following paragraph is indicative of the fear both of them feel at the moment. The readers can almost visualize the state of weakness Prim is experiencing by seeing her through Katniss' eyes as the latter speaks of "the blood drained from her face", the "hands clenched in fists at her sides", and the girl "walking with stiff, small steps". Such a description helps arouse the readers' sympathy towards Prim and helps anticipate Katniss' next step of volunteering in her stead for the Games. Describing Katniss' cry as "strangled" could be seen as conveying a feeling of suffocation under the shock, and it could also be seen as an indication of Katniss' coming back to her senses after the shock. This helps anticipate her next action of volunteering.

Katniss' horror is also reflected in the psychological sequencing in her narration. The sentence "[s]omeone is gripping my arm, a boy from the Seams" (paragraph 2) reflects Katniss' perception. Under the state of horror, she is unable at first to understand what is going on. She first feels an unidentified person gripping her arm, and then, she sees the boy who holds her as she is about to fall when she hears her sister's name. Hence, the way the information is arranged in the clauses serves to express Katniss' feelings of shock and horror.

Katniss also uses a number of indicators of thought and perception which help express her fear and disbelief. She uses, for instance, a number of modal verbs and hedging tools that are indicative of her point of view. The hedging tool "maybe" in addition to the verb of perception "think" in the sentence "I think maybe I started to fall and he caught me" indicate a 
great degree of uncertainty. Katniss is not even sure what is happening to her. She is so shocked that she seems to have lost track of what is happening even to her own body. The modal "must" in the sentence "[t]here must have been some mistake" (paragraph 2) is indicative of her shock and disbelief as she has taken all the necessary precautions so that her chances of being chosen as a tribute, and not her sister's, would be the ones who could be higher (by entering her name more than once), and it was for the sake of some extra food for her family. Katniss is almost frozen by surprise and fear, which makes her able to "hear" the unhappy murmurs of the crowd coming from "faraway" and "see" her sister walking feebly to the stage (paragraph 3). Through the description of Katniss' perception of her surroundings in this paragraph, the readers are able to perceive the situation through her senses and feel her temporary paralysis. This is before she comes back to her senses when she "sees" the tail of Prim's blouse tucking out of her skirt and decides to take action. Hence, the linguistic indicators of point of view in this extract portray Katniss' feelings of shock and horror and help the readers live the terrifying reaping ceremony through her feelings. Therefore, they could arouse the readers' terror as they help them imagine the inhumanity upon which a dystopian world is based, which serves as a warning against allowing such a regime to rule in the real world.

After Katniss volunteers to take part in the Games instead of her little sister, she is carried, along with the other tributes, to the Capitol where they are to be trained and prepared for the Games. Katniss provides a detailed description of what happens during the preparation for the Games like in the three following extracts:

"My quarters are larger than our entire house back home. They are plush, like the train car, but also have so many automatic gadgets that I'm sure I won't have time to press all the buttons. The shower alone has a panel with more than a hundred options you can choose regulating water temperature, pressure, soaps, shampoos, scents, oils, and massaging sponges. When you step out on a mat, heaters come on that blow-dry your body. Instead of struggling with the knots in my wet hair, I merely place my hand on a box that sends a current through my scalp, untangling, parting, and drying my hair almost instantly. It floats down around my shoulders in a glossy curtain." (Collins, 2008, pp. 91-92)

"You need only whisper a type of food from a gigantic menu into a mouthpiece and it appears, hot and steamy, before you in less than a minute. I walk around the room eating goose liver and puffy bread [...]" (Collins, 2008, p. 92)

"The creature standing before me in the full-length mirror has come from another world. Where skin shimmers and eyes flash and apparently they make their clothes from jewels. Because my dress, oh, my dress is entirely covered in reflective precious gems, red and yellow and white with bits of blue that accent the tips of the flame design. The slightest movement gives the impression I am engulfed in tongues of fire.

I am not pretty. I am not beautiful. I am as radiant as the sun.” (Collins, 2008, p. 146)

In the first extract, Katniss gives a detailed description of her room in the training centre the tributes are to stay at until the Games begin, and the description reflects how the room looks through her eyes and, hence, reflects her point of view. Katniss does not only describe her room as "large", but also as "larger than our entire house back home". She cannot stop comparing everything she sees and the luxury she has been showered with, since she got on the train to move the Capitol, to the poverty and need that are the norm at home. Another adjective (i.e. value-laden expression) which is telling is "glossy" which is used to describe Katniss' hair which she likens to a "curtail" in order to indicate how silky it has become after using all the tools available to her at the room. Katniss seems to be still unable to recognize herself with all 
the luxury available at the tip of her fingers since she has left home. Such luxury is expressed in the words she uses which reflect her schema (i.e. her knowledge of the world). There is a distinction between what Katniss seems to know and what she does not seem to know. Although she is able to identify "the soaps", "the shampoos", "the scents", "the oils" and the "massaging sponges", the phrase "so many automatic gadgets" reflects her ignorance of the other devices in her room, and hence, it reflects the deep sense of estrangement she has.

In the second extract, Katniss describes the food that is offered to her and that is not like any food she has ever tasted or will ever find during the Games. Her point of view is evident in the value-laden expressions she uses to describe the food. The food is "hot" and "steamy", which indicates how delicious it must be. Moreover, she can ask for any dish she wishes for from a menu which she describes as "gigantic". The adjective is not only indicative of the richness of the Capitol, but also of the huge budget that is allocated to the Games. The verb "whisper", which is an indicator of Katniss' perception, is also an indicator of the availability of all these luxuries for the tributes. They do not even need to ask anybody for the food; all they need is "whisper", and their wishes are commands.

In the third extract, Katniss describes herself after her stylist has prepared her for the Games. When she looks at her reflection in the mirror, she is unable to recognize herself, and the value-laden expressions she uses to describe her own reflection reveal a state of amazement. She describes herself as a "creature" which is indicative of how much she has transformed into another person she herself is unable to recognize. The detailed description she provides of her dress through using value-laden expressions is also telling. The dress is "entirely covered in reflective precious gems", and Katniss even names the colour of each and every gem in the dress; the gems are "red", "yellow", "white" and "blue". The dress is like no other Katniss has ever worn before. Katniss, in this dress which has been made with extreme care and distinguished skills, does not look only beautiful; she describes herself as being "as radiant as the sun", for she is almost glowing in this dress, and throughout the book, people will remember her as "the girl on fire". However, the dress is not the only thing that changes her appearance. Katniss uses expressions which are indicative of her perception. For example, the word "shimmers", which is attributed to her skin, and the word "flash", which is attributed to her eyes, show how she is seen through her own eyes after the great transformation she has undergone at the hands of her stylist and the preparation team. She is almost unable to recognize herself, for she has always been Katniss, the poor girl who has always struggled only to keep her family alive. The estrangement she feels also appears in her use of the third person pronouns "they" and "their" which are distal deictics. The pronouns are used to refer generally to the people of the Capitol, the richest place in Panem. The distal pronouns, used without adding a clear referent, are significant as they reflect Katniss' point of view. She seems to feel psychologically distant from the people of the Capitol. It is as if they live in a completely different world from her poor District 12 , let alone that they are the ruling party which is responsible for all her suffering both before the reaping and after it.

The three extracts, narrated from Katniss' point of view, are significant. On the one hand, they show the massive amount of money that is spent on the Games, which indicates the importance that the Capitol lays on these Games as a tool of reminding the population that they are at the government's mercy and subduing any potential future rebellion. On the other hand, the luxury that Katniss and the other tributes experience contrasts sharply with the poor miserable life they lead at home. The dress Katniss wears before the Games is like no other she has ever worn before, and wearing such a dress has probably never been part of even the happiest and the most far-fetched among her dreams. Moreover, being able to get food upon a whisper contrasts sharply with the moments during which she would search the garbage for 
food remains and the great happiness she felt when Peeta at some point in the past gave her a few burnt crusts of bread which she viewed as a precious meal. Making such luxury available to the tributes before throwing them into the arena to kill each other seems to be further humiliation. They are treated like sheep which are fed well before they are slaughtered. The dystopian world of Panem seems to be built not only on oppression, but also on humiliation.

The tributes are later taken in a helicopter to the arena, which is located in large woods, where each of the tributes has to face death at the hands of their fellow tributes, the game keepers and the wild nature. The following extract is part of Katniss' account of the horrifying days she has spent in the woods:

"I almost faint at the sight of my calf. The flesh is a brilliant red covered with blisters. I force myself to take deep, slow breaths, feeling quite certain the cameras are on my face. I can't show weakness at this injury. Not if I want help. Pity does not get you aid. Admiration at your refusal to give in does. I cut the remains of the pant leg off at the knee and examine the injury more closely. The burned area is about the size of my hand. None of the skin is blackened. I think it's not too bad to soak. Gingerly I stretch out my leg into the pool, propping the heel of my boot on a rock so the leather doesn't get too sodden, and sigh, because this does offer some relief. I know there are herbs, if I could find them, that would speed the healing, but I can't quite call them to mind. Water and time will probably be all I have to work with.” (Collins, 2008, p. 217)

In this extract, Katniss describes the excruciating pain inflicted on her by the burns she got from the fire opened on the tributes by the game makers as well as by the wounds she got during the Games. The value-laden expressions she uses are indicative of her suffering and misery. The adjectives "brilliant" and "red", in addition to the adjectival phrase "covered with blisters", which are all used to describe her calf, indicate how serious and even terrible her wound is. It is so terrible that she almost faints when she looks at it. Also, describing the wounded part of her leg as "the size of [her] hand" is telling of how grave and almost beyond repair her leg now is. Even though she is badly injured, Katniss cannot afford showing that she is in pain or else she would not get help. Therefore, she forces herself to take breaths which she describes as "deep" and "slow". Katniss at this point in the Games is deprived of a simple and basic human need; she is weak, and she is not even allowed to show it if she wants aids to be sent to her. The Capitol is intent on crushing the souls and humanity of its subjects by not allowing them even to show that they are in pain.

Katniss also uses a number of verbs and adverbs which are indicative of her thoughts and perception and which, accordingly, are also indicative of her point of view. The verb "feeling", followed by the adjectival phrase "quite certain", is indicative of Katniss' awareness that almost certainly a camera is now videotaping what she is doing. It is due to this feeling that she decides to appear strong because strength is rewarded, whereas weakness is condemned. The verb "think" in the sentence "I think it's not too bad to soak" indicates that Katniss is now starting to evaluate how treatable the injury is as well as her situation in the Games at large. The verb "know" in the sentence "I know there are herbs", in addition to the verb "call" preceded by the auxiliary "can' $t$ " in the clause "but I can't quite call them to mind", also indicate Katniss" view of the situation. Although Katniss "knows" about the herbs that can speed her recovery, her dizziness and pain make her unable to concentrate so that she could find them. Hence, the linguistic indicators of point of view in this extract indicate how miserable and drained Katniss is after spending days in the ferocious arena at the mercy of the game makers as well as the tributes. She is wounded, in pain and forced to hide her pain. The vulnerability that Katniss exhibits in this extract reflects the cruelty of the Capitol that does not 
refrain from crushing the souls of her citizens for the sake of having a firm grip on them and making them feel they are under its mercy.

One of the most horrifying experiences that the tributes go through during the Games is facing the mutts (short for "muttations") which are genetically altered animals used by the Capitol as weapons. In the following extract, Katniss relates part of her experience of facing the mutts:

"The mutts are beginning to assemble. As they join together, they raise up again to stand easily on their back legs giving them an eerily human quality. Each has a thick coat, some with fur that is straight and sleek, others curly, and the colors vary from jet black to what I can only describe as blond. There's something else about them, something that makes the hair rise up on the back of my neck, but I can't put my finger on it.

They put their snouts on the horn, sniffing and tasting the metal, scraping paws over the surface and then making high-pitched yipping sounds to one another. This must be how they communicate because the pack backs up as if to make room. Then one of them, a good-size mutt with silky waves of blond fur takes a running start and leaps onto the horn. Its back legs must be incredibly powerful because it lands a mere ten feet below us, its pink lips pulled back in a snarl. For a moment it hangs there, and in that moment I realize what else unsettled me about the mutts. The green eyes glowering at me are unlike any dog or wolf, any canine I've ever seen. They are unmistakably human. And that revelation has barely registered when I notice the collar with the number 1 inlaid with jewels and the whole horrible thing hits me. The blonde hair, the green eyes, the number . . it's Glimmer." (Collins, 2008, pp. 404-405)

The value-laden expressions that Katniss uses to describe the mutts are indicative of how scary they are. The adjectives that are used to describe their appearance like "sleek", "curly", "jet black" and "blond" are indicative of their various appearances, which paves the way for the shock that Katniss is later to discover. The adjective "human", preceded by the adverb "eerily", contributes to intensifying the sense of fear even though Katniss is still unable to identify what it is exactly that she is afraid of, but so far she can sense something human about these mutts. The adjectives "high-pitched" and "yipping" used to describe the sounds made by the mutts make them appear even more fearful through Katniss' eyes as she is able to guess that this is the way they communicate with each other, which means they are probably devising a plan to kill the tributes. Katniss' fear seems to be intensified in her use of the adjectives "good-size" and "powerful" (which is preceded itself by the adverb "incredibly") which are used to describe one of the mutts which is about to attack her. The adjectival phrase "unmistakably human" which is used to describe the mutt's eyes is indicative of Katniss' horrified recognition that the mutt attacking her is, in fact, one of the tributes that have been killed in the Games.

Psychological sequencing is another powerful technique of indicating viewpoint that contributes to creating a sense of horror and shock in this extract. The order of clauses in the extract reflects the development of Katniss' fear starting with her uneasiness about the mutts to her horror when she realizes that the mutt attacking her is a fellow tribute that has been killed. Katniss goes about describing the appearance of the mutts, stressing the fact that there is something scary about them which she is still unable to identify. This is before the readers start realizing the mutt through her eyes: "The blonde hair, the green eyes, the number...it's Glimmer." Ordering the clauses in the extract in this way helps the readers follow Katniss' thoughts while she is unable to identify the mutt until she is eventually shocked when she 
realizes what it really is. The Capitol has transformed her fellow tributes into mutts to use them to add fun to the Games by making them fiercer. In addition to the ordering of clauses, the verb "realize" in the sentence "I realize what else unsettled me about the mutts" is a verb which is indicative of Katniss' thoughts. It helps the readers delve into her mind and feel the shock she experiences the minute she "realizes" what the mutt really is. The linguistic indicators of Katniss' point of view in this extract, indeed, reflect the horror that fills her as well as the cruelty of such a dictatorship that does not mind using any kind of weapon to emphasize to the masses all the time that they are at its mercy.

\section{Conclusion}

The spike in the sales of dystopian works of art in recent years is significant. It is telling of the fear that has come to dominate the lives of the writers as well as the readers of this type of fiction. The analysis of one of such major works, which is Suzanne Collins' The Hunger Games, indicates how the linguistic tools used by the writer serve as a warning message. The linguistic indicators which are revealing of the I-narrator's point of view show how the protagonist and her people suffer under the rule of an authoritarian regime. Such linguistic choices serve to trigger the readers' imagination so that they would be able to have a vision of their own future if they allow authoritarianism to remain unchanged.

\section{A) Primary Sources}

\section{References}

Collins, S. (2008). The Hunger Games. New York: Scholastic Press.

\section{B) Secondary Sources}

Ames, M. (2011). Engaging "apolitical" adolescents: Analyzing the popularity and educational potential of dystopian literature post 9/11. The High School Journal, 9(1), 3-20. Retrieved from

https://www.researchgate.net/publication/265960351_Engaging_Apolitical_Adolescent s_Analyzing the_Popularity_and_Educational_Potential_of_Dystopian_Literature_Post $\underline{-911}$

Black, E. (2006). Pragmatic stylistics. Edinburg: Edinburg University Press.

Burke, B. R. (2014). "Reaping" environmental justice through compassion in The Hunger Games. $\quad$ Retrieved from https://lib.dr.iastate.edu/cgi/viewcontent.cgi?article=1002\&context=engl_pubs

Claeys, G. (2017). Dystopia: A natural history. Oxford: Oxford University Press.

Curwood, J. (2013). The Hunger Games: Literature, Literacy, and Online Affinity Spaces. Language Arts, 90(6), 417-427. Retrieved from https://mplbci.ekb.eg/MuseProxyID=1103/MuseSessionID=08100tprx/MuseProtocol =https/MuseHost=www.jstor.org/MusePath/stable/pdf/24575002.pdf?ab_segments $=0$ \%2Fbasic_search\%2Fcontrol\&refreqid=search\%3A48ce09e0d37618f68605998c25d1 $\underline{\mathrm{a} 0 \mathrm{a} 1}$

Davis, R. G. (2014). Writing the Erasure of Emotions in Dystopian Young Adult Fiction: Reading Lois Lowry's The Giver and Lauren Oliver's Delirium. Narrative Works: Issues, Investigations, \& Interventions, 4(2), 48-63. Retrieved from https://journals.lib.unb.ca/index.php/NW/article/view/22782/26458 
De Freytas-Tamura, K. (2017, January 25). George Orwell's '1984' is Suddenly a Best-Seller. The New York Times. Retrieved from https://www.nytimes.com/2017/01/25/books/1984-george-orwell-donald-trump.html

Dystopian Books See Impressive Sales Boost. (2017, March 10). CBS News. Retrieved from https://www.cbsnews.com/news/dystopian-books-see-impressive-sales-boost/

Finnsson, G. (2016). The unexpected popularity of dystopian literature: From Orwell's Nineteen Eighty-Four and Atwood's The Handmaid's Tale to Suzanne Collins' The Hunger Games Trilogy. Retrieved from https://skemman.is/bitstream/1946/26094/1/Geir\%20Finnsson.pdf

Gleyzer, M. (2018). Tomorrow's heroines fighting today's demons: Dystopia in The Hunger Games and Divergent series (Doctoral dissertation). Retrieved from https://mplbci.ekb.eg/MuseProxyID=1103/MuseSessionID=0811jtpkn/MuseProtocol $=\mathrm{https} /$ MuseHost=search.proquest.com/MusePath/docview/2054025667/F8C7019877 $\underline{\text { A6433DPQ/1?accountid }=178282}$

Hammond, A. (2017). Cold war stories: British dystopian fiction, 1945 - 1990. Brighton: Palgrave.

Hicks, H. J. (2016). The post-apocalyptic novel in the twenty-first century: Modernity beyond salvage. London: Palgrave.

Kirtley, P. M. (2011). The Hunger Games: Discussing dystopia. National Social Science Proceedings (pp. 119-123). Retrieved from https://www.academia.edu/2819055/The_Mind_Body_Connection_Technology_and_ Healthy_Aging

Leech, G. N., \& Short, M. H. (1981). Style in fiction: A linguistic introduction to English fictional prose. New York: Longman.

Leggatt, M. (2012). Melancholic and hunger games: Post-9/11 cinema and the culture of apocalypse. Retrieved from https://www.academia.edu/6711604/_Melancholic_and_Hungry_Games_Post9_11_Cinema_and the_Culture_of_Apocalypse

Mathichiparampil, S. (2016). The dystopian fixation: Roth's Divergent - A reflection of the post-apocalyptic trend in contemporary young adult fiction. Epitome, 2 (3), 179-186. Retrieved from http://epitomejournals.com/VolumeArticles/FullTextPDF/109_Research_Paper_179186.pdf

Miller, L. (2010, June 7). Fresh hell: What's behind the boom in dysptoian fiction or young readers? The New Yorker. Retrieved from https://www.newyorker.com/magazine/2010/06/14/fresh-hell-laura-miller

Paik, P. Y. (2010). From Utopia to apocalypse: Science fiction and the politics of catastrophe. University of Minnesota Press: Minnesota.

Short, M. (2013). Exploring the language of poems, plays and prose. New York: Longman. 